\title{
EGYES ARCHEOFITON TAXONOK ÉLETCIKLUSÁNAK JELLEMZÉSE 2017-BEN ÉS 2018-BAN
}

\section{LIFE CYCLE CHARACTERIZATION OF SOME ARCHAEOPHYTES IN 2017 AND 2018}

\author{
Ecseri Károly ${ }^{1^{*}}$, Honfi Péter ${ }^{2}$ \\ ${ }^{1}$ Kertészeti Tanszék, Kertészeti és Vidékfejlesztési Kar, Neumann János Egyetem \\ 2 Dísznövénytermesztési és Dendrológiai Tanszék, Kertészettudományi Kar, Szent István Egyetem \\ https://doi.org/10.47833/2020.2.AGR.002
}

\section{Kulcsszavak: \\ $\mathrm{BBCH}$ értékek \\ szántóföldi vadvirágok \\ fenológia \\ csapadékösszeg \\ hőösszeg}

\section{Keywords:}

$\mathrm{BBCH}$ values

wildflowers

phenology

annual precipitation

heat sum

\section{Cikktörténet:}

Beérkezett 2019. szept. 18.

Átdolgozva 2020. február 20.

Elfogadva 2020. február 25.

\begin{abstract}
Összefoglalás
Vizsgálatunkban egy szabadföldi mikroparcellás kísérlet keretében figyeltük meg néhány archeofiton faj fenológiai stádiumait. Az értékeléshez egy nemzetközileg elfogadott határozó kulcsot használtunk. Az eredmények alapján megállapitható, hogy a vizsgált fajok többsége képes áttelelni ( $T_{2}$-es életformájú fajok). A dekorációs időszakuk rövid, május második felétől június első dekádjáig tart, ez alól csupán a Malva sylvestris kivétel. Az őszi aszpektus kialakulását erősen befolyásolja a csapadék mennyisége, illetve a talajmüvelés időpontja. A fényért folytatott erös kompetíció káros hatású az alacsonyabb fajok generatív fázisára. A Cyanus segetum virágzásának lefutása és a dekorációs időszak alatt mért höösszegek között közepes erösségü korrelációt figyeltünk meg.

Abstract

Phenological stages of some archaeophytes was observed in a field micro parcel experiment. An internationally accepted growth stages was used for the evaluation. The majority of the examined species are able to overwinter (species with $T_{2}$ life form) based on the results. Their decoration period is short, it takes from the second half of May to the first decade of June, with the exception of Malva sylvestris. The emergence of the autumn succession is strongly influenced by the amount of precipitation and the time of tillage. Strong competition for light has a detrimental effect on the generative phase of smaller species. Correlation was observed between the flowering time of Cyanus segetum and the heat sum during the decoration period.
\end{abstract}

\section{Bevezetés}

Az archeofitonok olyan, az adott terület szempontjából eredetileg nem honos fajok, melyek a vizsgált területen 1500 (1492) elött meghonosodtak [6]; [11]; [14]. Az európai flórakutatásban „ójövevényeknek” [1], régi antropofitonoknak is nevezik öket, megkülönböztetésül a neofitonoktól [15], melyek Amerika felfedezését követően kerültek be az európai flórába.

\footnotetext{
* Kapcsolattartó szerző. Tel.: +36 76517 655;

E-mail cím: ecseri.karoly@kvk.uni-neumann.hu
} 
Ezen archeofitonok elsősorban a természetközeli kertek növényalkalmazási koncepciójába illeszthetőek bele, hiszen ezeknek a zöldfelületeknek a tulajdonságai (természetes táj közvetlen közelében kerül kialakításra, alapfajok alkalmazása, szerényebb dekorációs értékü növények, sok taxon, minimális ápolás) állnak legközelebb az archeofitonok jellemzőihez [10]. Az egyszerü szaporításnak (illetve szaporodásnak) köszönhetően a parasztkertekben is elöszeretettel alkalmazzák a Consolida regalis, Cyanus segetum, vagy a Papaver rhoeas fajokat [12].

Ezen taxonok felhasználására, illetve megörzésére elsősorban a mezőgazdasági területeken találunk szakirodalmi adatokat. Az Örségi Nemzeti Parkban végzett három éves kísérletben egy 2 hektáros szántóból lett legelőt műveltek meg, és vetettek be régi gabonafajtákkal, illetve a helyi flórából gyűjtött archeofiton taxonokkal (Agrostemma githago, Bromus secalinus, Camelina alyssum, Cyanus segetum, Lolium remotum, Lolium temulentum, Veronica agrestis). A tapasztalatok alapján a fejlődő állományra a tél végi legeltetés káros hatású, emellett a kezdeti években jelentős az Ambrosia artemisiifolia borítása a területen. Ennek is köszönhetö, hogy fenntartási feladatoknak komoly anyagi és élőmunka igénye van [7]; [13], és megállapítható, hogy a szántók mellett található gyepes szegélyek nem jelentenek menedéket ezen fajok számára: igazi refúgiumként a termesztett kultúrák közvetlen szegélye a kiemelkedő fontosságú [4].

$A z$ in situ védelmi lehetőségek mellett másik felhasználási mód a vadvirágos gyepek, magkeverékek alkalmazása. Több cég is forgalmaz ilyen termékeket, például a Rieger-Hofmann $\mathrm{GmbH}$, melynek vadvirág keverékében 14 archeofiton taxon található. Domináns fajok az Agrostemma githago illetve a Cyanus segetum. A javasolt mennyiség $2 \mathrm{~g} / \mathrm{m}^{2}$. A fenntartás során késő őszi kaszálást javasol a szaporítóanyag forgalmazója [16].

Egy kísérletes körülmények között alkalmazott vadvirágos szegély Svájcban az alábbi taxonokból állt: Achillea millefolium, Agrostemma githago, Centaurea jacea, Cichorium intybus, Cota tinctoria, Cyanus segetum, Daucus carota, Dipsacus fullonum, Echium vulgare, Hypericum perforatum, Leucanthemum vulgare, Malva moschata, Malva sylvestris, Origanum vulgare, Papaver rhoeas, Pastinaca sativa, Silene latifolia subsp. alba, Tanacetum vulgare, Verbascum lychnitis, Verbascum thapsus [2]. Ezek közül négy faj (Agrostemma githago, Cichorium intybus, Malva sylvestris, Papaver rhoeas) a magyar archeofiton listában is szerepel.

A fentieken túl az archeofitonok dísznövények alkalmazhatóak közutak, autópályák melletti peremszegélyek, rézsűk zöldítésére, illetve hulladéklerakók, valamint homok- és kavicsbányák bolygatott felszínének díszítésére [8]. Zöldtetöre ajánlott archeofiton fajok az Anthemis arvensis, Cyanus segetum, Consolida regalis és a Papaver rhoeas [5]. De akár a nagyvárosokban is létesíthető belölük úgynevezett R-stratégiás egynyári virágágy. Ezt az alkalmazási módot például építkezések, felújítások területén javasolják, mint ideiglenes takarást biztosító, természetes hatást nyújtó zöldfelületet, melynek fenntartási költsége igen alacsony. Létesíthető többek között Orlaya grandiflora - akár önálló - alkalmazásával is [9].

\section{Módszer}

A kísérlet helyszíne egy Cegléd melletti házikert, melynek talaja humuszos homok. A terület évelő gyomoktól mentes, a kísérlet beállítása előtt szervesanyag-utánpótlásban részesült. A vetés 2013. április 18-án történt egyenletesen elmunkált talajba, sekélyen bedolgozva, majd beöntözve.

A fajok összeválogatásának alapelve az volt, hogy ezek a növények egyazon asszociációnak (Secalietea) a tagjai természetes körülmények között. Az elvetett összes magmennyiség 8,33 g volt

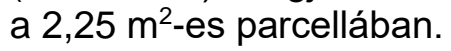

A terület - a kelesztő öntözésen kívül - vízutánpótlást nem kapott. Agrotechnikai eljárást 2017. augusztus 7-én és 2018. december 9-én végeztünk talajforgatás formájában. Szervesanyagfeltöltés és -elhordás sem történt. A parcella magbankjának gyarapítására Vicia villosa-t vetettünk 2013. június 23-án.

Az értékelés az intenzív vegetatív fejlődési és a virágzási csúcsidőszakban heti két-három alkalommal, egyébként pedig heti egy alkalommal történt.

A fejlődési sebességet a BBCH azonosító kulcsok segítségével [3] hasonlítottuk össze, melynek értékei az alábbiak:

10 - 19: Levél fejlődés (fö hajtáson)

20 - 29: Oldalhajtások kialakulása, bokrosodás 
30 - 39: Hajtásmegnyúlás, föhajtás növekedése

40 - 49: Vegetatív szaporítás, bugavirágzat fejlődés - kalászolás (évelöknél, füveknél)

50 - 59: Virágzat megjelenés a föhajtáson, fejesedés - virágzás (füveknél)

60 - 69: Virágzás a föhajtáson

70 - 79: Termésfejlődés

80 - 89: Érés vagy termés- és magfejlődés

90 - 97: Öregedés, a nyugalom kezdete

A meteorológiai adatok nyomon követésével értékeltük az egyes taxonok virágzási periódusa alatt tapasztalt hőmérséklet- és csapadékviszonyokat.

A statisztikai kiértékelés során regresszió-analízist alkalmaztunk, lineáris és nemlineáris függvények segítségével. A szignifikáns differenciát a Tukey-teszt, LSD és a Games-Howell teszt alapján határoztuk meg $(\alpha=0,05)$. Az elemzésekhez az SPSS 20 -as programcsomagot alkalmaztuk (IBM, New York, US).

\section{Eredmények}

\subsection{A 2017-es vegetációs periódus}

2017-ben 5 archeofiton jelent meg a kísérleti parcellán. Az elöző évben jelenlévő, őszi aszpektusban fejlödött fajok közül a Vaccaria hispanica elpusztult, a többi három (Malva sylvestris, Cyanus segetum, Papaver rhoeas) viszont áttelelt és tőlevélrózsás állapotban volt április első dekádjáig. Március második dekádjától volt megfigyelhető a Vicia villosa, illetve a Stachys annua. Ez utóbbi végig vegetatív stádiumban maradt, bimbófejlődést, illetve virágzást nem tapasztaltam. Hasonló megfigyelést tettem a Malva sylvestris esetében is: ennek a fajnak az egyedét a másik két domináns növény (Cyanus segetum és Papaver rhoeas) kiszorította.

Az agrotechnikai beavatkozást követöen ugyanakkor mind az 5 archeofiton ismét megjelent a területen: már augusztus 3. dekádjában csírázott a Malva sylvestris és a Cyanus segetum, de szeptember közepén megjelent a Papaver rhoeas és a Stachys annua is. November 11-étöl pedig a Vicia villosa egyedei is megfigyelhetőek voltak. Az előző vegetációs periódusban jelen lévő Ajuga chamaepitys, Nigella arvensis és Vaccaria hispanica ebben az évben nem jelentek meg a területen.

A virágzás ebben a vizsgálati évben a Cyanus segetum-mal indult. A fészekvirágzatok május 4 és augusztus 4 között díszítettek. A höösszeg a virágzás kezdetén 600 , a végén $2500{ }^{\circ} \mathrm{C}$ volt. $\mathrm{Az}$ akmé idején (június 8) az összes virágzat száma $104 \mathrm{db}$ volt. Az ezt megelőző két hétben nem volt csapadék a területen, a napi középhömérséklet pedig $21-22{ }^{\circ} \mathrm{C}$ között alakult. A höösszegek és a maximális virágzati számok illeszkedés vizsgálata igen erős volt. A harmadfokú függvénnyel leírt kapcsolat szerint ez a meteorológiai paraméter 83,5 \%-ban játszott szerepet a virágzás változásában. A csapadékösszegek tekintetében az illeszkedés mértéke közepes $\left(R^{2}=0,53\right)$.

A Papaver rhoeas dekorációs periódusa május 10 és június 21 között volt megfigyelhetö. a virágzási időszak alatt $25 \mathrm{~mm}$ csapadék hullott. A legtöbb egyszerre nyíló virág $(67 \mathrm{db})$ május 28-án jelent meg az állományban. Az akmét megelőzően (május 25-én) egy rövid hideg periódus $\left(5^{\circ} \mathrm{C}-\mathrm{os}\right.$ hőmérséklet csökkenés) volt kiolvasható az adatokból.

A harmadik virágzó archeofiton a Vicia villosa volt 2017-ben. A pillangós virágok május 20-án kezdtek nyílni, a dekorációs periódus vége június 21-ére esett. A csúcspont május 31-én volt, 109 $\mathrm{db}$ egyszerre nyíló fürttel. Az akmé előtt $5^{\circ} \mathrm{C}$-os átlaghőmérséklet emelkedés volt megfigyelhető.

Az összesített virágzási időszak május 4-től augusztus 4-ig tartott. Ebből május 20 és június 21 között virágzott mindhárom faj egyidejüleg.

$\mathrm{A} \mathrm{BBCH}$ értékek elemzésekor részletesebb fenológiai információk is megállapíthatóak a parcellán lévő archeofitonok fejlődésével kapcsolatban. A tavaszi aszpektusban nem csak a tölevélrózsás stádium (BBCH 10-19) látható mind az 5 faj esetében, hanem az is megfigyelhetö, hogy a hajtások elágazásokat fejlesztettek (BBCH 20-29) a Vicia villosa és a Cyanus segetum esetében. A hajtások megnyúlása (BBCH 30-39) a Papaver rhoeas esetében nem esett egybe a másik két vegetatív paraméterrel, hanem közvetlenül követte a tölevélrózsás állapotot. $A$ hajtásnövekedés második felében már a bimbók kialakulása (BBCH 50-59) is megkezdődött ennél a fajnál, illetve a Cyanus segetum esetében. Az agrotechnikai beavatkozásnak köszönhetően a Cyanus segetum-nál a virágzás, érés és szeneszcencia végpontja ugyanazon napra esett. Az őszi 
aszpektusban a Papaver rhoeas és a Malva sylvestris a vizsgálat végéig tölevélrózsás állapotban maradt, míg a Vicia villosa és a Cyanus segetum esetében már a hajtások növekedését is megfigyeltük. A Stachys annua ebben az évszakban oldalhajtásokat is fejlesztett, melyekböl $6 \mathrm{db}$ alakult ki december elejéig (1. ábra).

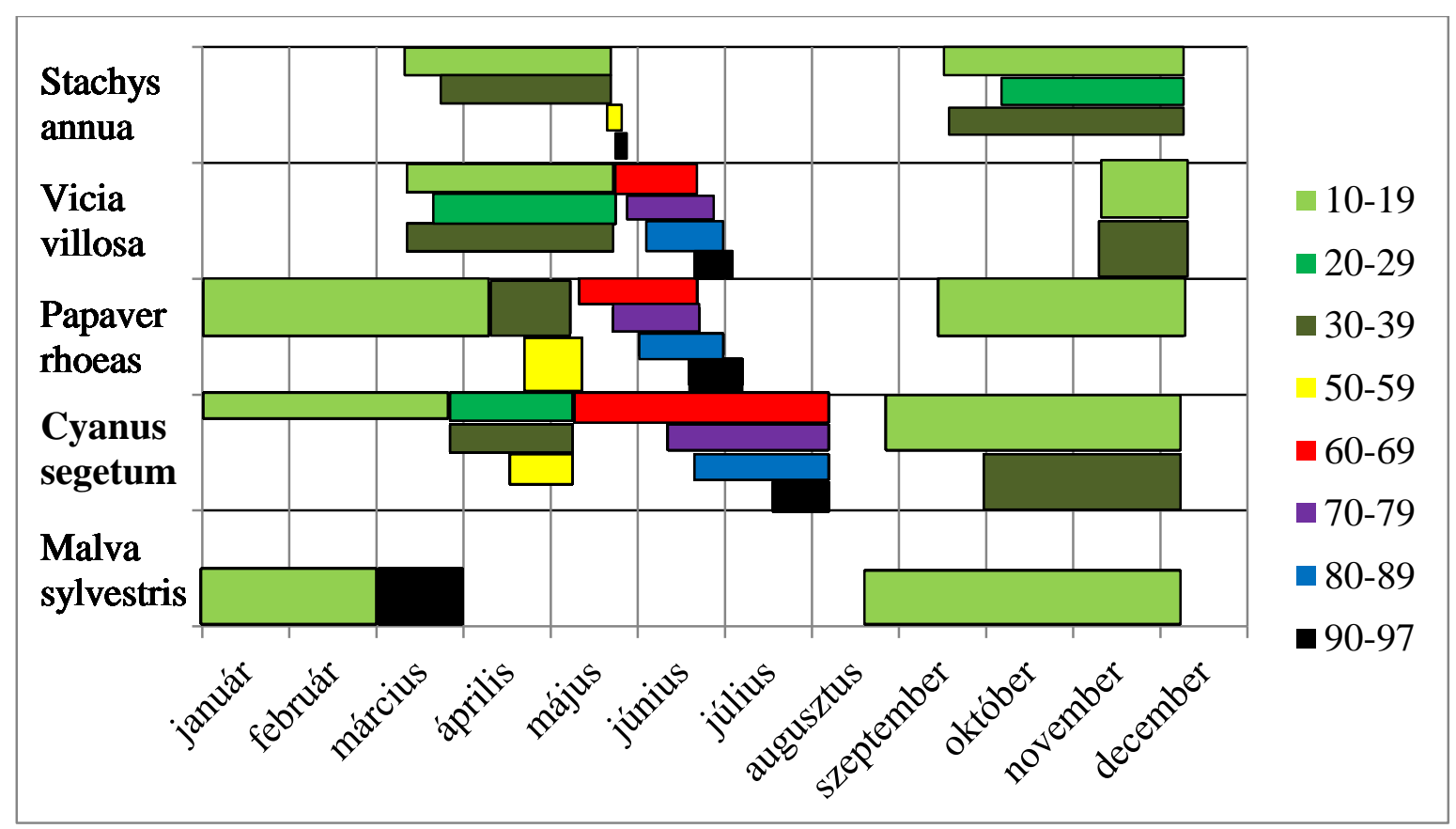

1. ábra. Archeofiton taxonok fenogramja a BBCH skála alapján, a 2017-es évben, in situ mikroparcellás díszítöérték-vizsgálatban (Cegléd)

\subsection{A 2018-as vegetációs periódus}

A következő vizsgálati évben 6 archeofiton faj volt jelen a vizsgálati parcellán. A 2017-es év őszi aszpektusában megjelent 5 faj (Cyanus segetum, Malva sylvestris, Papaver rhoeas, Stachys annua, Vicia villosa) mindegyike áttelelt. Emellett ismét megjelent a területen a Vaccaria hispanica néhány példánya. A Stachys annua hajtása eltört a hónyomás hatására, majd a megfigyelt két egyed március 30-án eltünt a területröl. Bár a vegetációs periódus a vizsgált archeofitonok többségénél július utolsó napjaiban befejeződött, a Malva sylvestris virágzása miatt a talajforgatást csak az első talajmenti fagyok után végeztem el (2. ábra).

A dekorációs periódusok közül elsőként a Cyanus segetum virágzatai voltak megfigyelhetök ebben az évben. A virágzási időszak április 29 -én kezdődött $\left(740^{\circ} \mathrm{C}\right.$ höösszegnél) és július 21 -ig tartott ( $2470{ }^{\circ} \mathrm{C}$ höösszegig). A legtöbb egyszerre nyíló fészek május 17 -én volt megfigyelhető (20 $\mathrm{db}$ ). A virágzás csúcsa kiegyenlített volt, ezt a 15-20 közötti értéket június 4-éig megtartotta az állomány. Ebben az időszakban csapadék nem hullott, a napi középhőmérséklet pedig fokozatosan emelkedett 16-ról $23{ }^{\circ} \mathrm{C}$-ra. A hőösszegek illeszkedés vizsgálatakor számított determinációs együttható értéke közepes volt $\left(R^{2}=0,522\right)$, hasonlóan a csapadékösszegek vizsgálatakor kapott eredményhez $\left(R^{2}=0,465\right)$.

A Malva sylvestris május 14-töl november 25-ig virágzott. Ez alatt az időszak alatt $220 \mathrm{~mm}$ csapadék hullott, a hőösszeg pedig $3900{ }^{\circ} \mathrm{C}$-kal gyarapodott. A dekorációs periódusban nem volt szünet, az állományban (kb. $30 \mathrm{db}$ egyed) mindig volt virágzó példány ezalatt a több mint fél éves időszak alatt. Az akmé július 12-én volt, ekkor 129 db virágot vételeztünk fel a parcellán. A virágzási csúcs előtt 3-5 nappal $10 \mathrm{~mm}$ csapadék hullott. A vizsgált két meteorológiai paraméter közepes mértékben magyarázta a virágzás lefutását $\left(R^{2}=0,578\right.$ a hőösszegek; $R^{2}=0,486 \quad a$ csapadékösszegek esetében). 
A Papaver rhoeas esetében május 4. és június 7. között zajlott a dekorációs időszak. Ebben az egy hónapos intervallumban egy mérési időpontban nem volt virágzó egyed az állományban (június 1-én). Ezért a 2. ábrán látható skála is két részböl áll. A virágzás csúcspontja május 17-én volt, ekkor $69 \mathrm{db}$ virág volt ebböl az archeofitonból. Az őszi aszpektusban egy csekély mértékü másodvirágzást figyeltünk meg október 27. és november 2. között. Statisztikailag igazolható kapcsolat nem volt a vizsgált két meteorológiai paraméter esetében.

Megvizsgálva a Vicia villosa virágzására vonatkozó adatokat, megállapítható, hogy virágzása május 4. és június 11 . között történt, 850 és $1600^{\circ} \mathrm{C}$ höösszeg értékek között, megszakítás nélkül, június 1-ei akmével. A virágzás csúcspontján $94 \mathrm{db}$ fürtöt detektáltunk. Az alacsony mintaelemszám miatt sem itt, sem a következő fajnál nem végeztünk regresszió-vizsgálatot.

Május 9-én kezdődött a Vaccaria hispanica első virágzási periódusa. Bár a május 26-i értékeléskor nem volt nyíló virág az állományban, de ezt követően a dekorációs időszak folytatódott, egészen június 7-éig. A legtöbb virágot $(26 \mathrm{db})$ az első mérési időpontban produkálta az állomány.

Az összesített virágzási időszak április 29. és november 25. között zajlott a 2018-as vegetációs ciklusban. Ebben az időszakban elvégzett 53 mérési időpont közül 6 olyan alkalom volt, amikor mind az 5 vizsgált archeofiton faj dekorációs periódusa átfedte egymást. Ezek a következőek: május 1422. között, május 29-én, illetve június 4-7 között.

A 2018-as vizsgálati évben végzett részletes fenológiai megfigyelések alapján megállapítható, hogy jelentős változás az áttelelt archeofitonok állapotában nem történt egészen március első dekádjáig. Ekkor indult meg a Malva sylvestris hajtásainak megnyúlása. Dinamikus fejlödés volt megfigyelhető a Papaver rhoeas esetében április második felében, melynek végén már a bimbók is megjelentek ennek a fajnak az egyedein. Bár a Malva sylvestris virágzása folyamatos volt, ennek az archeofitonnak a generatív fázisát mégis két részre lehet osztani, mely érzékelhető a 33. ábrán látható termésfejlődésben és érésben. A virágzati szárak kidőltek, és itt július első dekádjára befejeződött a virágnyílás. Ugyanakkor a hajtások legmagasabb pontján fejlődő bimbókból folytatódott a dekorációs időszak, melyet 20-30 nap késéssel követett a termések növekedése is. A piros, lila és kék szakasz azonos végpontja jelzi, hogy ez az állomány még nem fejezte be a vegetációs periódusát november végén sem, de a jelentős lehülés miatt a növények elpusztultak.

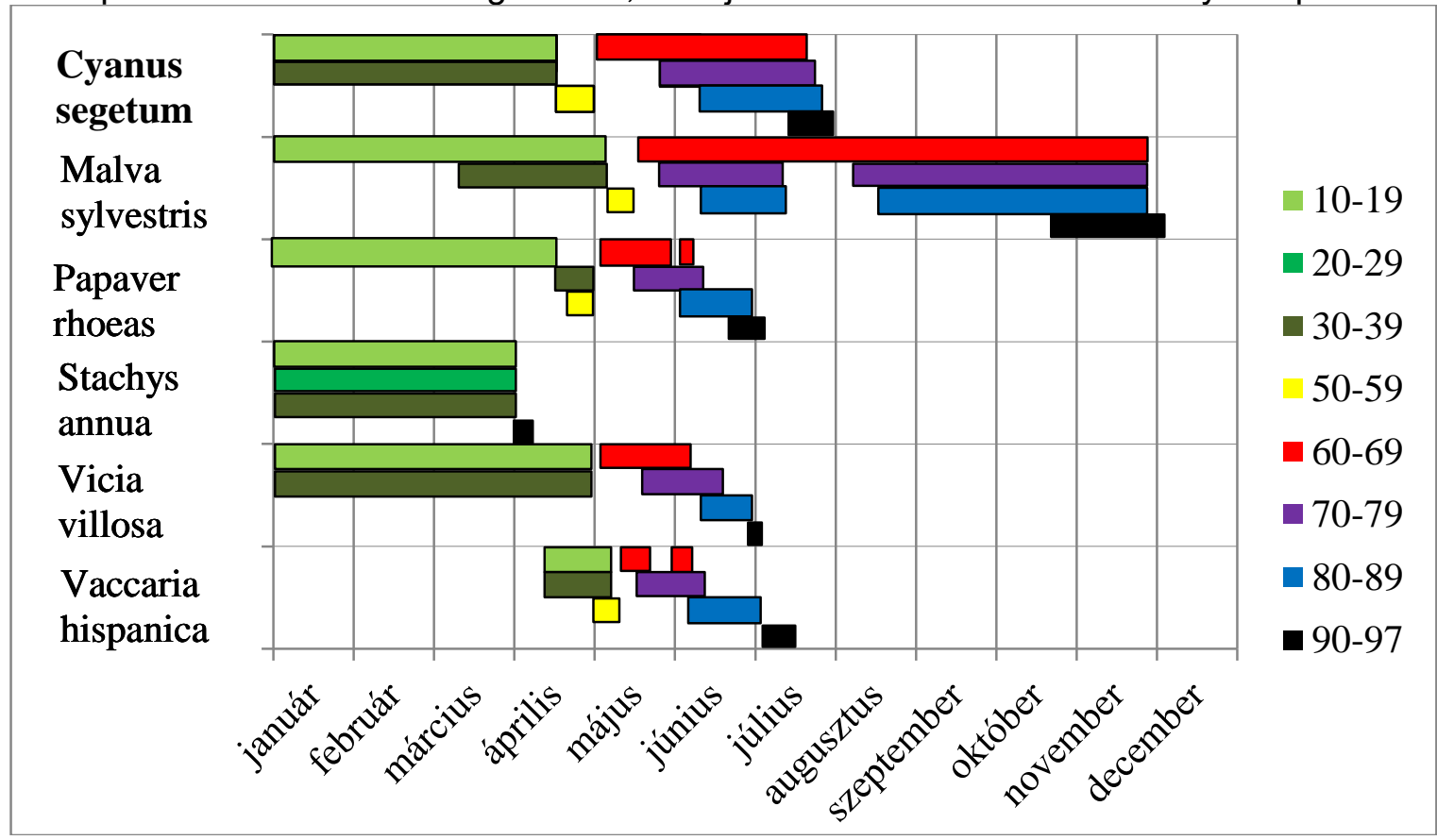

2. ábra. Archeofiton taxonok fenogramja a BBCH skála alapján, a 2018-as évben, in situ mikroparcellás díszitöérték-vizsgálat (Cegléd)

Megjegyzés: 10-19: levél fejlődés; 20-29: oldalhajtások fejlődése; 30-39: hajtásmegnyúlás; 50-59: virágzat megjelenése, 60-69: virágzás; 70-79: termésfejlödés; 80-89: termésérés; 90-97: öregedés. 


\section{Következtetések}

A két vizsgálati évet összehasonlítva megállapítható, hogy a Cyanus segetum, a Malva sylvestris és a Papaver rhoeas a 2016-17-es, illetve a 2017-18-as télen is áttelelt. A dominancia viszonyok alapján a 2017-es évben a parcellán a búzavirág és a pipacs volt uralkodó, míg 2018-ban a mályva tekinthető hasonlóan jelentősnek. Az átlagos virágzási időszak 2017-ben 56 nap, míg 2018-ban 76 nap volt. Kiemelkedő volt a Cyanus segetum virágzása 93 nap (2017-ben), 84 nap (2018-ban), valamint a Malva sylvestris dekorációs időszaka 196 nap (2018-ban). A legnagyobb díszítőértékkel a parcella mindkét évben május második felétől június elejéig rendelkezett. A 2017es évvel szemben 2018-ban nem alakult ki őszi aszpektus a területen (feltehetően az alacsony csapadékmennyiség miatt).

\section{Köszönetnyilvánítás}

Köszönettel tartozunk a kutatás támogatásáért, amely az EFOP-3.6.2-16-2017-00012 „Funkcionális, egészséges és biztonságos élelmiszer termékpálya modell kidolgozása a szántóföldtől az asztalig elv alapján, tematikus kutatási hálózatban" pályázat keretében valósult meg. A projekt a Magyar Állam és az Európai Unió támogatásával, az Európai Szociális Alap társfinanszírozásával, a Széchenyi 2020 program keretében valósul meg.

\section{Irodalomjegyzék}

[1] BALOGH L. (2003): Az adventív terminológia s. I. négynyelvű segédszótára, egyben javaslat egyes szakszavak magyar megfelelőinek használatára. Botanikai Közlemények, 90 (1-2) p. 65-93.

[2] HAALAND, C., GYLLIN, M. (2011): Sown Wildflower Strips - A Strategy to Enhance Biodiversity and Amenity in Intensively Used Agricultural Areas. p. 155-172. In: LOPEZ-PUJOL, J. (Ed.): The Importance of Biological Interactions in the Study of Biodiversity. Croatia: InTech.

[3] HESS, M., BARRALIS, G., BLEIHOLDER, H., BUHR, L., EGGERS, TH., HACK, H., STAUSS, R. (1997): Use of the extended $\mathrm{BBCH}$-scale - general for the description of the growth stages of mono- and dicotyledonous weed species. Weed research, 37 p. 433-441.

[4] KIRÁLY A., KIRÁLY G., NAGY A. (2006): Veszélyeztetett szegetális gyomfajok megőrzési lehetőségei nagytáblás, intenzív mezőgazdálkodás mellett. Kitaibelia, 11 (1) p. 59.

[5] KUMPFMÜLLER, M. (2008): Wege zur Natur in kommunalen Freiräumen. Linz: Oberösterreichische Akademie für Umwelt und Natur. 227. p.

[6] MASLO, S., ABADŽı́́, S. (2015): Vascular flora of the town of Bragaj (south Bosnia and Herzegovina). Natura Croatica, 24 (1) p. 59-92.

[7] MESTERHÁZY A. (2005): Veszélyeztetett gyomfajok megőrzése az Örségi Nemzeti Park területén. p. 43. In: LENGYEL Sz., SÓLYMOS P., KLEIN Á. (Szerk.): Az III. Magyar Természetvédelmi Biológiai Konferencia Program és Absztrakt kötete. Budapest: Magyar Biológiai Társaság.

[8] MEYER, S., HILBIG, W., STEFFEN, K., SCHUCH, S. (2013): Ackerwildkrautschutz - Eine Bibliographie. Bonn: Bundesamt für Naturschutz. p. 47.

[9] PÁPAI V., BÍRÓ B. (2016): Ökologikus zöldfelületek városi alkalmazása. Budapest: Fökert Nonprofit Zrt. p. 50-55, 88, 90.

[10] PATKÓS I., KOVÁCS E. (2018): Az évelő dísznövények felhasználása. Budapest: Szerzői magánkiadás.

[11] PYSEK, P. et al. (2012): Catalogue of alien plants of the Czech Republic (2nd edition): Checklist update, taxonomic diversity and invasion patterns. Preslia, 84 p. 155-255.

[12] SCHMIDT G. (Szerk.) (2003): Növények a kertépítészetben. Budapest: Mezőgazda Kiadó. p. 213-220.

[13] SZÉPLIGETI M., MESTERHÁZY A., PINKE GY., CSISZÁR Á., SCHMIDT D., BARTHA D. (2012): Arable Weed Conservation Programme In Örség National Park. p. 4. In: NEMÉNYI, M., HEIL, B. (Szerk.): The Inpact of Urbanization, Industrial and Agricultural Technologies on the Natural Environment: International Scientific Conference on Sustainable Development and Ecological Footprint. Budapest: Nemzeti Tankönyvkiadó.

[14] TERPÓ, A., ZAJĄC, M., ZAJĄC, A. (1999): Provisional list of Hungarian archeophytes. Thaiszia - Journal of Botany, 9 p. 41-47.

[15] ZAJĄC, M., ZAJĄC, A., TOKARSKA-GUZIK, B. (2009): Extinct and endangered archaeophytes and the dinamics of their diversity in Poland. Biodiversity Research and Conservation, 13 p. 17-24.

[16] https://www.rieger-hofmann.de/sortiment/mischungen/begruenungen-fuer-den-stadt-und-siedlungsbereich/12feldblumenmischung.html. Keresőprogram: Google. Kulcsszavak: Feldblumenmischung. Lekérdezés időpontja: 2019.07.18. 